\title{
NEW RECORDS AND REMARKS ON EARTHWORMS OF THE VOJVODINA PROVINCE (OLIGOCHAETA: LUMBRICIDAE, CRIODRILIDAE)
}

\author{
Jovana M. Sekulić1 Mirjana M. Stojanović-Petrović², \\ Tanja B. Trakić2 , Filip J. Popović2* \\ ${ }^{1}$ University of Kragujevac, Institute for Information Technologies Kragujevac, \\ Department of Science, Jovana Cvijića bb, 34000 Kragujevac, Serbia \\ ${ }^{2}$ University of Kragujevac, Faculty of Science, Institute of Biology and Ecology, \\ Radoja Domanovića 12, 34000 Kragujevac, Serbia \\ *Corresponding author; E-mail: filip.popovic@pmf.kg.ac.rs
}

(Received March 6 2021; Accepted April 7, 2021)

\begin{abstract}
The aim of this paper is to present the results of the recent collecting earthworms, with new localities and new habitats in Vojvodina Province. The sporadic field investigation was carried out during 2013-2020. In this paper we report new records of Criodrilus lacuum Hoffmeister, 1845 (family Criodrilidae) proved to be new species for the fauna of Vojvodina Province. Also, information on the taxonomic status of individual species was provided. Fifteen earthworm species and subspecies from family Lumbricidae have been registered. Six taxa were found to be synonymous with nominal species, so that the number decreases to 31 species, from 10 genera. Our data demonstrate clearly that the earthworm fauna of the Vojvodina Province is relatively poor, monotonous and that the impact of intensification of agricultural practices effect on loss of soil biodiversity.
\end{abstract}

Keywords: earthworms, Oligochaeta, Lumbricidae, Criodrilidae, Vojvodina Province.

\section{INTRODUCTION}

Vojvodina Province is extremely flat area formed after the swelling of the Pannonian Sea. It is situated in the southeastern part of the Pannonian plain. The monotony of the plain break up rivers, canals, sandstone, loess plateau, different crops and other vegetation, densely distributed settlements, and two mountains, whose height barely exceed the upper limit of the hills, and all this gives a special landscape appearance. Natural vegetation is still dominant in only a few very restricted areas. Agriculture, forestry, urbanization, and water management have had profound influences on the distribution, structure, and quality of habitats and species. For these reasons formed several protected areas such as: Fruška Gora Mountain, the Vršac Mountains (also known as Vršac Hill), Danube Basin and Zasavica. The protected areas which represent a major wildlife refuge have a great importance for the preservation of biodiversity (CSUZDI, 1995; ZICSI et al., 1999; BÁLDI, 2003; CSUZDI and ZICSI, 2003; BĂNĂDUC, 2009; COVACIU-MARCOV et al., 2009; FERENTI et al., 2013). 
While the taxonomic composition and distribution of earthworms of certain parts of the Pannonian Plain are well known (POP, 1948, 1949; ZICSI, 1991; MRŠIć, 1991; CSUZDI and ZICSI, 2003; POP et al., 2010; CSUZDI et al., 2011; SZEDERJESI, 2011), some parts of the region have not been widely studied. Research of earthworms in Vojvodina Province were started at the beginning of the XX century (SZÜTS, 1919; ČERNOSVITOV, 1938). ZICSI (1972) and ŠAPKAREV (1978) continued to work on Lumbricidae Vojvodina Province. These investigations were followed by ŠAPKAREV (1986), MRŠIĆ and ŠAPKAREV (1987), MRŠIĆ (1991), STOJANOVIĆ et al. (2008), MILUTINOVIĆ et al. (2010). The first larger and significant expedient investigation has been carried out by Stojanović and Milutinović (2014) and StOjANOvić et al. (2014) and resulted in eight species recorded for the first time in the Vojvodina Province (Allolobophora mehadiensis voivodinensis Šapkarev, 1989, Aporrectodea macvensis (Šapkarev, 1987), Dendrobaena veneta veneta (Rosa, 1886), Bimastos rubidus (Eisen, 1874), Lumbricus friendi Cognetti, 1904, Octodrilus gradinescui (Pop, 1938), Octolasion cyaneum (Savigny, 1826) and Proctodrilus opisthoductus Zicsi, 1985 and two of these species were identified for the first time throughout the whole territory of Serbia ( $L$. friendi and $O$. gradinescui).

This list of earthworms of Vojvodina Province included 31 species belonging to 10 genera. However, the difference in the number of species between the last work from 2014 and the present checklist is a result of the fact that two taxa were found to be synonymous with nominal species (STOJANOVIĆ et al., 2020). Also, four subspecies was found to be synonymous to the nominal species already reported for the Pannonian Plain.

In that respect, one of our aims has been to present the results of the recent collecting, with a new localities and a new habitats. Another aim was to present the valuable data that we came across from the old collection of our Institute. We report the first record of Criodrilus lacuum Hoffmeister, 1845, in Serbia, thus updating the knowledges of its geographical range.

\section{MATERIALS AND METHODS}

Our investigations were carried out in the Vojvodina Province, located in the northern part state of Serbia $\left(44^{\circ} 38^{\prime}-46^{\circ} 10^{\prime} \mathrm{N} ; 18^{\circ} 10^{\prime}-21^{\circ} 15^{\prime} \mathrm{E}\right)$ (Fig. 1). Vojvodina extends to the southern part of the Pannonian Region and is a predominantly flat area with two mountain ranges, Fruška gora Mt. and Vršac Mts. Fruška Gora is a low island mountain, located at 502 m.a.s.l., while Vršac Mts. is a low island mountain, located at 641 m.a.s.l. Its valleys are covered by meadows, while its highest parts are covered by the dense deciduous forests. The climate is temperate-continental with central-European and Mediterranean influences. More than $75 \%$ of the territory is occupied by agricultural fields which alternate with forests, meadows and pastures.

The sporadic field investigation was carried out during 2013-2020. Over the last investigation period, from all over the territory, we were collecting earthworms from various habitats which included natural biotopes (oak forest, wet meadow, under the stump, near the river, near the stream, mud) and artificial biotopes (garden and agricultural field).

Earthworms were collected using the diluted formaldehyde method complemented with digging $(0.4 \times 0.4 \mathrm{~m}$ quadrates) and hand sorting as well as turning over rocks, debris and logs. The earthworms were killed in $70 \%$ ethanol, immediately fixed in $4 \%$ formalin solution and transferred and stored in 90\% ethanol. Species identification was made according to the complex features provided in ŠAPKAREV (1978), ZICSI (1985), MrŠIĆ (1991), CsUZDI and ZICSI (2003) and BLAKEMORE (2004). 


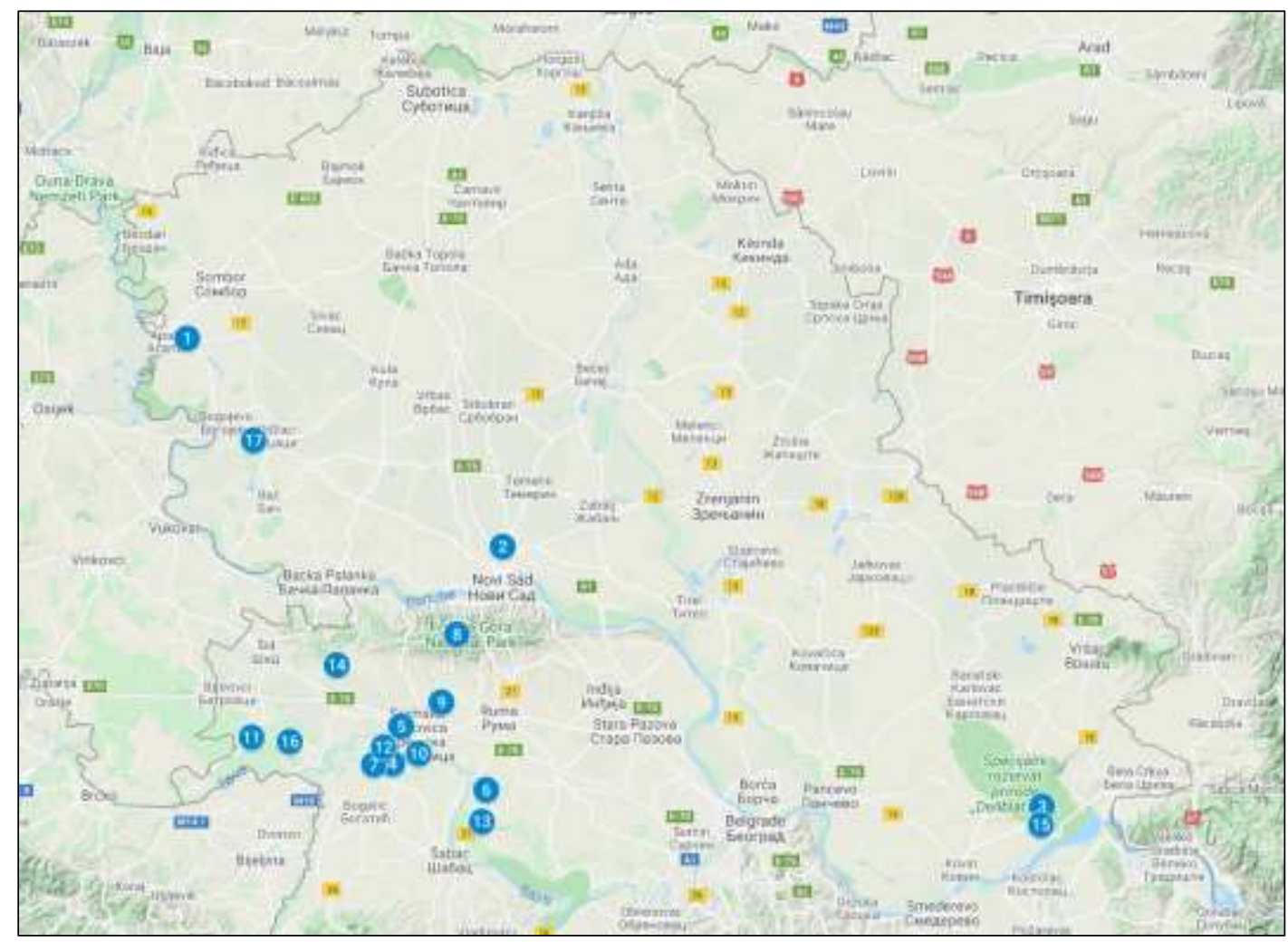

Figure 1. Map showing the study localities in the Vojvodina Province (1 - Banja Junaković, 2 - Rimski Šančevi, 3 - Dubovac, 4 - Noćaj, 5 - Laćarak, 6 - Hrtkovci, 7 - Radenković, 8 - Fruška Gora, 9 - Veliki Radinci, 10 - Salaš Noćajski, 11 - Morović, 12 - Zasavica, 13 - Platičevo, 14 - Erdevik, 15 - Šumarak, 16 - Višnjićevo, 17 - Karavukovo).

\section{RESULTS AND DISCUSSION}

During the present study, 15 species and subspecies of earthworms from family Lumbricidae have been registered in Vojvodina Province (Tab. 1). Six taxa were found to be synonymous with nominal species (Tab. 2). By combining these new findings with the previous studies (STOJANOvić et al., 2014; SzEDERJESI et al., 2014), the number of species from family Lumbricidae known to be occurring in the studied region decreases to 31 species from 10 genera. Also, Criodrilus lacuum from the family Criodrilidae proved to be new for the fauna of Vojvodina Provance (Tab. 1).

In the Vojvodina Province, according to our results, the most common species is Aporrectodea chlorotica (Savigny, 1826) which occurs only in the agricultural field and it is a typical synanthropic species. The next most common species are: Ap. trapezoides (Dugès, 1828), Ap. rosea (Savigny, 1826) and Lumbricus terrestris Linnaeus, 1758. High abundance in this group of species reflects their reproductive capacity and the potential to adapt and colonization (Bouché, 1977; Satchell, 1980). Based on the study that was conducted Stojanović and Milutinović (2014), it can be observed a correlation between the type of habitats and species of earthworms that occur in them. In our researches, there are a lot of agricultural habitats, which are characteristic for these earthworm species (Schmidt et al., 2001, 2003; Krück et al., 2006; Scullion et al., 2006; Pelosi et al., 2009a, b). In particular, Ap. trapezoides and Ap. rosea occur commonly in soils used for grain production (Baker et al., 2003). Otherwise, cropping systems thus modify the functional composition of earthworms (Pelosi et al., 2009b). 
Table 1. List of the collected lumbricid taxa and their localities (2013-2020).

\begin{tabular}{lll}
\hline Species & Habitat & Localities \\
\hline
\end{tabular}

Fam. Lumbricidae

Allolobophora chlorotica chlorotica (Savigny, 1826)

Agricultural field

\section{Allolobophora leoni Forest, wet} Michaelsen, 1891 meadow

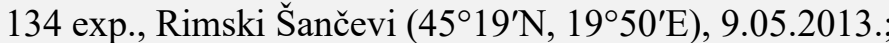
34 exp., Rimski Šančevi $\left(45^{\circ} 19^{\prime} \mathrm{N}, 19^{\circ} 50^{\prime} \mathrm{E}\right), 15.11 .2013$; 132 exp., Rimski Šančevi ( $\left.45^{\circ} 19^{\prime} \mathrm{N}, 19^{\circ} 50^{\prime} \mathrm{E}\right), 3.06 .2014$; 130 exp., Rimski Šančevi $\left(45^{\circ} 19^{\prime} \mathrm{N}, 1^{\circ} 50^{\prime} \mathrm{E}\right), 15.09 .2014$.;

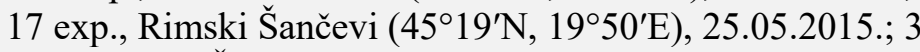
exp., Rimski Šančevi $\left(45^{\circ} 19^{\prime} \mathrm{N}, 19^{\circ} 50^{\prime} \mathrm{E}\right), 9.09 .2015 ; 58$ exp., Rimski Šančevi ( $\left.45^{\circ} 19^{\prime} \mathrm{N}, 19^{\circ} 50^{\prime} \mathrm{E}\right), 22.04 .2016$.

1 exp., Apatin, Banja Junaković $\left(45^{\circ} 40^{\prime} \mathrm{N}, 18^{\circ} 58^{\prime} \mathrm{E}\right)$, 26.06.2015.; 1 exp., Dubovac $\left(44^{\circ} 47^{\prime} \mathrm{N}, 21^{\circ} 12^{\prime} \mathrm{E}\right)$,

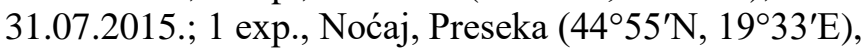
13.06.2016.

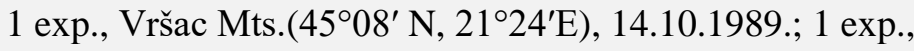
Allolobophora robusta Forest Rosa, 1895

Aporrectodea rosea (Savigny, 1826)

Oak forest, agricultural field

Višnjičevo $\left(44^{\circ} 57^{\prime} \mathrm{N}\right.$; $\left.19^{\circ} 17^{\prime} \mathrm{E}\right), 10.07 .2013 . ; 1$ exp., Laćarak $\left(45^{\circ} 00^{\prime} \mathrm{N}, 1^{\circ} 34^{\prime} \mathrm{E}\right), 01.07 .2014$.; 1exp., Hrtkovci $\left(44^{\circ} 52^{\prime} \mathrm{N}, 19^{\circ} 46^{\prime} \mathrm{E}\right), 10.07 .2014$.

1 exp., Radenković, Pačja Bara $\left(44^{\circ} 55^{\prime} \mathrm{N}, 19^{\circ} 29^{\prime} \mathrm{E}\right)$, 11.04.2013.; 2 exp., Rimski Šančevi ( $\left.45^{\circ} 19^{\prime} \mathrm{N}, 19^{\circ} 50^{\prime} \mathrm{E}\right)$, 09.05.2013.; 8 exp., Rimski Šančevi $\left(45^{\circ} 19^{\prime} \mathrm{N}, 19^{\circ} 50^{\prime} \mathrm{E}\right)$, 15.11.2013.; 2 exp., Rimski Šančevi $\left(45^{\circ} 19^{\prime} \mathrm{N}, 1^{\circ} 50^{\prime} \mathrm{E}\right)$, 15.09.2014.; 2 exp., Rimski Šančevi $\left(45^{\circ} 19^{\prime} \mathrm{N}, 19^{\circ} 50^{\prime} \mathrm{E}\right)$, 9.09.2015.; 2 exp., Rimski Šančevi $\left(45^{\circ} 19^{\prime} \mathrm{N}, 19^{\circ} 50^{\prime} \mathrm{E}\right)$, 22.04.2016.

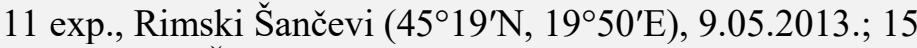
exp., Rimski Šančevi $\left(45^{\circ} 19^{\prime} \mathrm{N}, 19^{\circ} 50^{\prime} \mathrm{E}\right), 15.11 .2013$.; 14

Aporrectodea trapezoides (Dugès, 1828)

Agricultural field, forest exp., Rimski Šančevi ( $\left.45^{\circ} 19^{\prime} \mathrm{N}, 19^{\circ} 50^{\prime} \mathrm{E}\right), 3.06 .2014$.; 7 exp., Rimski Šančevi $\left(45^{\circ} 19^{\prime} \mathrm{N}, 19^{\circ} 50^{\prime} \mathrm{E}\right), 15.09 .2014$.; 3 exp., Rimski Šančevi $\left(45^{\circ} 19^{\prime} \mathrm{N}, 19^{\circ} 50^{\prime} \mathrm{E}\right), 25.05 .2015 . ; 1$

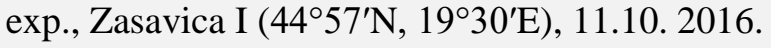

Aporrectodea dubiosa

Mud

(Örley, 1881)

\section{Dendrobaena} octaedra

(Savigny, 1826)

Eisenia fetida

(Savigny, 1826)

Eisenia lucens

(Waga, 1857)

Lumbricus friendi

Cognetti, 1904

Lumbricus rubellus Hoffmeister, 1843
Meadow, forests, under the stump

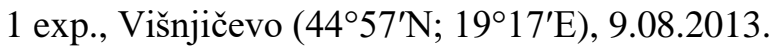

3 exp., Fruška gora $\left(45^{\circ} 09^{\prime} \mathrm{N}, 19^{\circ} 43^{\prime} \mathrm{E}\right)$, 6.07.2019.

1 exp., Rimski Šančevi $\left(45^{\circ} 19^{\prime} \mathrm{N}, 19^{\circ} 50^{\prime} \mathrm{E}\right), 25.05 .2015$.

field

Agricultural

field ,near the stream

2 exp., Laćarak $\left(45^{\circ} 00^{\prime} \mathrm{N}, 19^{\circ} 34^{\prime} \mathrm{E}\right), 1.07 .2014 . ; 2$ exp.,

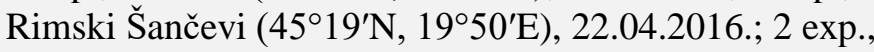
Fruška gora $\left(45^{\circ} 09^{\prime} \mathrm{N}, 19^{\circ} 43^{\prime} \mathrm{E}\right), 6.07 .2019$.

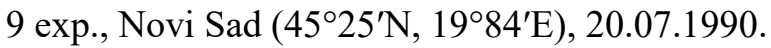

1 exp., Veliki Radinci $\left(45^{\circ} 02^{\prime} \mathrm{N}, 19^{\circ} 40^{\prime} \mathrm{E}\right), 25.06 .2014$.; 1 exp., Salaš Noćajski $\left(44^{\circ} 56^{\prime} \mathrm{N}, 19^{\circ} 35^{\prime} \mathrm{E}\right), 13.07 .2014$.; 1

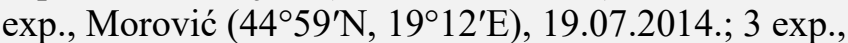

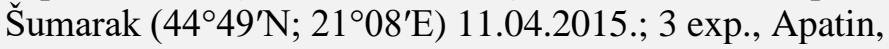
Banja Junaković $\left(45^{\circ} 40^{\prime} \mathrm{N}, 18^{\circ} 58^{\prime} \mathrm{E}\right), 26.06 .2015 . ; ~ 3$ exp., Višnjičevo (44 $57^{\circ} \mathrm{N}$; $\left.19^{\circ} 17^{\prime} \mathrm{E}\right), 11.03 .2017$. 
Table 1. continued

\begin{tabular}{|c|c|c|}
\hline $\begin{array}{l}\text { Lumbricus terrestris } \\
\text { Linnaeus, } 1758\end{array}$ & $\begin{array}{l}\text { Garden, } \\
\text { meadow, forest, } \\
\text { coast. }\end{array}$ & $\begin{array}{l}2 \text { exp., Veliki Radinci }\left(45^{\circ} 02^{\prime} \mathrm{N}, 19^{\circ} 40^{\prime} \mathrm{E}\right), 25.06 .2014 . ; 1 \\
\text { exp., Veliki Radinci }\left(45^{\circ} 02^{\prime} \mathrm{N}, 19^{\circ} 40^{\prime} \mathrm{E}\right), 28.06 .2014 . ; 2 \\
\text { exp., Laćarak }\left(45^{\circ} 00^{\prime} \mathrm{N}, 19^{\circ} 34^{\prime} \mathrm{E}\right), 1.07 .2014 . ; 3 \text { exp., } \\
\text { Hrtkovci }\left(44^{\circ} 52^{\prime} \mathrm{N}, 19^{\circ} 46^{\prime} \mathrm{E}\right), 10.07 .2014 . ; 3 \text { exp., } \\
\text { Morović }\left(44^{\circ} 59^{\prime} \mathrm{N}, 19^{\circ} 12^{\prime} \mathrm{E}\right), 19.07 .2014 . ; 2 \text { exp., } \\
\text { Platičevo }\left(44^{\circ} 49^{\prime} \mathrm{N}, 19^{\circ} 47^{\prime} \mathrm{E}\right), 30.07 .2014 . ; 1 \text { exp., } \\
\text { Zasavica I, }\left(44^{\circ} 57^{\prime} \mathrm{N}, 19^{\circ} 30^{\prime} \mathrm{E}\right), 11.10 .2016 . ; 3 \text { exp., } \\
\text { Radenković, Vrbovac }\left(44^{\circ} 55^{\prime} \mathrm{N}, 19^{\circ} 29^{\prime} \mathrm{E}\right), 29.10 .2016 . ; 2 \\
\text { exp., Erdevik }\left(45^{\circ} 07^{\prime} \mathrm{N} ; 19^{\circ} 24^{\prime} \mathrm{E}\right), 23.03 .2017 . ; 1 \text { exp., } \\
\text { Sremska Mitrovica }\left(44^{\circ} 58^{\prime} \mathrm{N}, 19^{\circ} 36^{\prime} \mathrm{E}\right), 10.10 .2015 . ; 1 \\
\text { exp, Sremska Mitrovica }\left(44^{\circ} 58^{\prime} \mathrm{N}, 19^{\circ} 36^{\prime} \mathrm{E}\right), 19.10 .2015 . ; \\
1 \text { exp., Sremska Mitrovica }\left(44^{\circ} 58^{\prime} \mathrm{N}, 19^{\circ} 36^{\prime} \mathrm{E}\right), \\
25.12 .2019 . ; 1 \text { exp., Sremska Mitrovica }\left(44^{\circ} 58^{\prime} \mathrm{N},\right. \\
\left.19^{\circ} 36^{\prime} \mathrm{E}\right), 07.03 .2020 . ; 1 \text { exp., Sremska Mitrovica } \\
\left(44^{\circ} 58^{\prime} \mathrm{N}, 19^{\circ} 36^{\prime} \mathrm{E}\right), 20.03 .2020 .\end{array}$ \\
\hline $\begin{array}{l}\text { Octolasion lacteum } \\
\text { (Örley, 1881) }\end{array}$ & $\begin{array}{l}\text { Near the Sava } \\
\text { River, forest }\end{array}$ & $\begin{array}{l}1 \text { exp., Radenković, Pačja Bara }\left(44^{\circ} 55^{\prime} \mathrm{N}, 19^{\circ} 29^{\prime} \mathrm{E}\right), \\
11.04 .2013 . ; 1 \text { exp., Ravnje, Trebljevine }\left(44^{\circ} 56^{\prime} \mathrm{N},\right. \\
\left.19^{\circ} 25^{\prime} \mathrm{E}\right) 2.04 .2015 . ; 1 \text { exp., Ravnje, Batve }\left(44^{\circ} 56^{\prime} \mathrm{N},\right. \\
\left.19^{\circ} 25^{\prime} \mathrm{E}\right), 19.06 .2016 . ; 1 \text { exp., Radenković, Vrbovac } \\
\left(44^{\circ} 55^{\prime} \mathrm{N}, 19^{\circ} 29^{\prime} \mathrm{E}\right), 29.10 .2016 . ; 2 \text { exp., Erdevik } \\
\left(45^{\circ} 07^{\prime} \mathrm{N} ; 19^{\circ} 24^{\prime} \mathrm{E}\right), 23.03 .2017 . ; \text { exp., Temerin, Jegrička } \\
\text { obala }\left(45^{\circ} 24^{\prime} \mathrm{N}, 19^{\circ} 53^{\prime} \mathrm{E}\right), 25.07 .2020 \text {. }\end{array}$ \\
\hline $\begin{array}{l}\text { Octodrilus } \\
\text { complanatus } \\
\text { (Dugès, 1828) }\end{array}$ & Forest & 1 exp., Dubovac $\left(44^{\circ} 47^{\prime} \mathrm{N}, 21^{\circ} 12^{\prime} \mathrm{E}\right), 31.07 .2015$. \\
\hline $\begin{array}{l}\text { Octodrilus } \\
\text { transpadanus } \\
\text { (Rosa, 1884) }\end{array}$ & $\begin{array}{l}\text { Near the Sava } \\
\text { River, forest }\end{array}$ & $\begin{array}{l}1 \text { exp., Zasavica, Turske livade }\left(44.95^{\circ} \mathrm{N}, 19.53^{\circ} \mathrm{E}\right), \\
\text { 19.11.2013.; } 1 \text { exp., Salaš Noćajski }\left(44^{\circ} 57^{\prime} \mathrm{N}, 19^{\circ} 35^{\prime} \mathrm{E}\right) \text {, } \\
\text { 7.08.2013.; } 1 \text { exp., Hrtkovci }\left(44^{\circ} 52^{\prime} \mathrm{N}, 19^{\circ} 46^{\prime} \mathrm{E}\right), \\
\text { 10.07.2014.; } 1 \text { exp., Zasavica I }\left(44^{\circ} 57^{\prime} \mathrm{N}, 19^{\circ} 30^{\prime} \mathrm{E}\right), 11.10 . \\
\text { 2016.; } 1 \text { exp., Erdevik }\left(45^{\circ} 07^{\prime} \mathrm{N} ; 19^{\circ} 24^{\prime} \mathrm{E}\right), 23.03 .2017 .\end{array}$ \\
\hline
\end{tabular}

Fam. Criodrilidae

Criodrilus lacuum Mud and roots

Hoffmeister, 1845 of aquatic plants

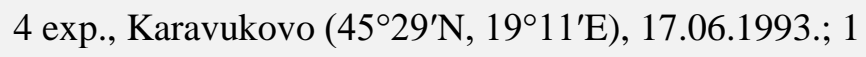

exp., Karavukovo $\left(45^{\circ} 29^{\prime} \mathrm{N}, 19^{\circ} 11^{\prime} \mathrm{E}\right), 11.07 .1993 . ; 17$

exp., Karavukovo $\left(45^{\circ} 29^{\prime} \mathrm{N}, 19^{\circ} 11^{\prime} \mathrm{E}\right), 12.07 .1993$.

Table 2. Lumbricid taxa excluded from the checklist of Vojvodina Province.

\begin{tabular}{|c|c|}
\hline Species name & Explanation \\
\hline $\begin{array}{l}\text { Allolobophora kosowensis kosowensis } \\
\text { Karaman, } 1968\end{array}$ & $=$ All. kosowensis Karaman, 1968 \\
\hline $\begin{array}{l}\text { Allolobophora mehadiensis voivodinensis } \\
\text { Šapkarev, } 1989\end{array}$ & $\begin{aligned}= & \text { All. } \text { m. boscaiui Pop, } 1948, \\
& \text { (SZEDERJESI et al., 2014) }\end{aligned}$ \\
\hline $\begin{array}{l}\text { Allolobophora robusta robusta } \\
\text { Rosa, } 1895\end{array}$ & $=$ All. robusta Rosa, 1895 \\
\hline $\begin{array}{l}\text { Dendrodrilus rubidus rubidus } \\
\text { (Savigny, 1826) }\end{array}$ & $=$ Bimastos rubidus (Savigny, 1826) \\
\hline $\begin{array}{l}\text { Dendrodrilus rubidus subrubicundus } \\
\text { (Eisen, 1874) }\end{array}$ & $=$ Bimastos rubidus (Savigny, 1826) \\
\hline $\begin{array}{l}\text { Fitzingeria platyura depressa } \\
\text { (Rosa, 1893) }\end{array}$ & $=$ Dendrobaena depressa $($ Rosa, 1893$)$ \\
\hline
\end{tabular}


Lumbricus friendi is European species, known mainly from the Atlantic region of Europe (BOUCHE, 1972). This species has been introduced to the USA (CsUZDI and SZLAVECZ, 2003). The first finding of $L$. friendi in Vojvodina Province (STOJANOvić et al., 2014) was in the area of Fruška Gora Mt. (Iriški Venac, 450 m.a.s.l.). However, based on our old Institute collection this species lives, as well, on the lower altitudes (near 80 m.a.l.s.). Therefore, the easternmost limit of distribution of this species is Pannonian part of Serbia. The fact that $L$. friendi occurs in northern Serbia in only two locations indicates that it is probably a recent introduction.

The degree of endemism in the Pannonian area of Serbia is relatively low, with five taxa (three Dacian and two Balkanic endemics) (Stojanović et al., 2020). Dacian endemics are the most representative element in endemic earthworm fauna of the Romanian Carpathians (CSUZDI et al., 2011), with the Apuseni Mountains where the distribution center is located (BODNARIUC et al., 2002; PoP et al., 2010; CsUZDI et al., 2011). Five Dacians stenoendemas are present only in the Apuseni Mountains, while spreading widespread Dacian endemics occupy lower altitudes (Pop et al., 2010) and inhabit the Pannonian Plain between the Carpathians and the Danube. Two subspecies are also present in the Pannonian part of Serbia: All. mehadiensis mehadiensis Rosa, 1895 and All. mehadiensis boscaiui Pop, 1948. However, Dacian endemic All. mehadiensis is a polytypic species quite variable in the number of segments in clitellum and tubercles. The position of the clitellum and tubercles in the subspecies boscaiui and voivodinensis is almost identical and, therefore, according to SZEDERJESI et al. (2014) All. mehadiensis voivodinensis is synonym of All. mehadiensis boscaiui Pop, 1948. Based on this data, number of endemic species decreased to 5 taxa in relation to the report they gave Stojanović and Milutinović (2014). Endemic species All. mehadiensis mehadiensis, known from South Romania, Bulgaria (MinAILOVA, 1964), East Hungary (CsuZDI and ZICSI, 2003; Csuzdi et al., 2011) and east part of Vojvodina (StojAnOvić and MilutinOvić, 2014). However, under the name All. mehadiensis voivodinensis Šapkarev, 1989 this species registered in east Vojvodina (Stojanović and Milutinović, 2014) and in east Serbia (SzEDERJESI, 2013). The other subspecies All. mehadiensis oreophila Pop, 1978 has been known from the southwestern Romania and the western Carpathians (CSUZDI et al., 2011) and does not registered in Vojvodina Province. Octodrilus gradinescui is another endemic species of Dacian origin and it occurs in Romania, Slovakia, Ukraine, and Hungary (CsuZDI and ZICSI, 2003; CsuZDI et al., 2011). Two endemic taxa, Allolobophora kosowensis Karaman, 1968 and Aporrectodea macvensis (Šapkarev, 1987), belong to the broad range Balkan endemic species, registered in the Balkan part of Serbia and in the only one locality on the border between the Pannonian Plain and the Balkan Peninsula (StOJAnOvić and Milutinović, 2014). Allolobophora kosowensis has been registered mainly in the southern and southeastern part of Serbia. Based on the distribution data of this species, it is certain that it is the hilly area of Serbia around the river Velika Morava possible migratory road to the northernmost point of its distribution on the perimeter Pannonian Basin. Aporrectodea macvensis is a rare endemic species. It is represented mainly in the western and northern part Balkan part of Serbia (Milutinović et al., 2015; Stojanović and MilutinOvić, 2014; STOJANOvić et al., 2018).

Except the family Lumbricidae, in the Vojvodina Province for the first time is registered one species from the family Criodrilidae. Criodrilus lacuum Hoffmeister, 1845 is aquatic species which widely distributed in Europe and common all around the Mediterranean (MISIRLIOĞLU, 2012). This is peregrine species, distributed worldwide (Blakemore, 2008). So far in Serbia this species found only in the Danube River (AtANACKOvić et al., 2013). Near the border with Bosnia and Herzegovina, we have found 22 examples of C. lacuum and it is the first finding place in Vojvodina Province.

Vojvodina Province is from all sides surrounded by mountains, by the Alps in the west, the Dinarides in the south, the Carpathian Mts. in the north and the east, and the Balkan Mts. in the southeast. In geomorphological and ecological terms, mountains have had a significant 
impact on biodiversity in the Pannonian Plane (PoP et al., 2010; CsuzDI et al., 2011). On the other hand, due to the agriculture impacts, the earthworm fauna of the Vojvodina Province is on the distinct stress of anthropogenic factors which are unification of living conditions. Therefore, it is understandable that the number of endemic earthworms from Pannonian part of Serbia is quite low compared with the 25 endemic taxa recorded from the Balkan part of Serbia (Stojanović et al., 2020). Only one Dacian endemic, O. gradinescui does not present in the Balkan part of Serbia. Four other endemics from Vojvodina Province exist in the Balkan part of Serbia, as well. Despite of the fact that is the Vojvodina Province is a much smaller part of the country, our data demonstrate clearly that the earthworm fauna of the Vojvodina Province is relatively poor and monotonous. It is clear that the impact of intensification of agricultural practices effect on loss of soil biodiversity (HolE et al., 2005) and therefore it is not surprising that peregrine species are predominant. On the other hand, we cannot ignore the fact that the Balkan Peninsula is a specific region with frequent changes in global ecological conditions throughout geological history that have greatly contributed to the occurrence of an exceptionally heterogenous fauna in this area (MRŠIĆ, 1991). However, instead of prevalence of distinctly uniform agrobiotopes that affect on the unification of living conditions that strongly endanger biodiversity in Vojvodina, there are still natural areas which deserve protection, and that could maintain the functioning of natural ecosystems and act as refuge for earthworm species.

\section{Acknowledgments}

This work was supported by the Serbian Ministry of Education, Science and Technological Development (Agreement No. 451-03-9/2021-14/200378 and 451-03-9/202114/200122).

\section{References:}

[1] Atanacković, A., Šporka, F., Csányi, B., Vasiljević, B., Tomović, J., Paunović, M. (2013): Oligochaeta of the Danube River - a faunistical review. Biologia 68 (2): 269-277. doi: 10.2478/s11756-013-0155-9.

[2] BAKer, G.H., Amato, M., LADD, J. (2003): Influences of Aporrectodea trapezoides and A. rosea (Lumbricidae) on the uptake of nitrogen and yield of oats (Avena fatua) and lupins (Lupinus angustifolius). Pedobiologia 47: 857-862. doi:10.1078/0031-405600271.

[3] BÁLDI, A. (2003): Using higher taxa as surrogates of species richness: a study based on 3700 Coleoptera, Diptera, and Acari species in Central-Hungarian reserves. Basic and Applied Ecology 4: 589-593. doi: 10.1078/1439-1791-00193

[4] BĂNĂDUC, D.S. (2009): Lower Timiş River (Banat, Romania). Special area for conservation (Natura 2000 site) for Gobio albipinnatus Lukasch, 1933. AACL Bioflux 2 (2): 147-151.

[5] BlaKemore, R. (2004): A provisional list of valid names of Lumbricoidea (Oligochaeta) after Easton, 1983. Editorial Complutense, Madrid, Spain: Universidad Complutense, pp. $75-120$.

[6] Bodnariuc, A., Bouchette, A., Dedoubat, J.J. (2002): Holocene vegetational history of the Apuseni Mountains, central Romania. Quaternary Science Reviews 21: 1465-1488.

[7] Bouché, M.B. (1972): Lombriciens de France. Écologie et Sysématique. Institut National de la Recherche Agronomique. Articles de Zoologie-Écologie animale (Numéro horssérie). pp. 671. 
[8] BouchÉ, M.B. (1977): Strategies Lombriciennes. Ecological Bulletins 25: 122-132.

[9] ČERnosvitov, L. (1938): Zur Kenntnis der Oligochätenfauna des Balkans. V. Oligochäten aus Jugoslawien und Albanien Zoologischen Anzeiger 122: 285-289.

[10] Cognetti, L. (1904): Lombricidi dei Pirenei. Bollettino dei Musei di Zoologia ed Anatomia comparata della $R$. Universitá di Torino 19 (476): 1-14.

[11] Covaciu-Marcov, S.D., Sas, I., Cicort-lucaciu, A.Ş., Kovacs, E.H., Pintea, C. (2009): Herpetofauna of the natural reserves from Carei plain: zoogeographical significance, ecology, statute and conservation. Carpathian Journal of Earth and Environmental Sciences 4 (1): 69-80.

[12] CSUZDI, C. (1995): The earthworm fauna of Örség landscape conservation area (Oligochaeta, Lumbricidae). Natural History of Örség Landscape Conservation Area I, Savaria Múzeum, Szombathely 22: 37-42.

[13] CsuzDI, C. (2012): Earthworm species, a searchable database. Opuscula Zoologica Budapest 43: 97-99.

[14] Csuzdi, C., Pop, V.V., Pop, A.A. (2011): The earthworm fauna of the Carpathian Basin with new records and description of three new species (Oligochaeta: Lumbricidae). Zoologischer Anzeiger 250: 2-18.

[15] Csuzdi, C., Szlávecz, K. (2003): Lumbricus friendi Cognetti, 1904 a new exotic earthworm in North America. Northeastern Naturalist 10 (1): 77-82.

[16] Csuzdi, C., Zicsi A. (2003): Earthworms of Hungary, Pedozoologica Hungarica No1. Hungary Natural History Museum and Hungary Academy of Sciences, Budapest. doi: $10.5281 /$ zenodo.4309820

[17] DugÈs, A. (1828): Recherche sur la circulation, la respiration, et la reproduction des Annélides sétigéres abranches. Annales des Sciences Naturelles Paris 15: 284-336.

[18] EISEN, G. (1874): New Englands och Canadas Lumbricides. Öfversigt af Kongliga Vetenskaps-Akademiens Förhandligar 31 (2): 41-49.

[19] Ferenti, S., Cupsa, D., Sas-Kovács, É.H., Sas-Kovács, I., Covaciu-Marcov, S.D. (2013): The importance of forests and wetlands from the Tur River natural protected area in conservation of native terrestrial isopod fauna. North-Western Journal of Zoology 9 (1): 139-144.

[20] Hoffmeister, W. (1843): Beitrag zur Kenntnis Deutscher Landanneliden. Archiv für Naturgeschichte 9: 183-198.

[21] HofFMEISTER, W. (1845): Übersicht aller bis jetzt bekannten Arten aus der Familie der Regenwürmer. Friedrich Vieweg and Sohn, Braunschweig, 43 pp.

[22] Hole, D.G., Perkins, A.J., Wilson, J.D., Alexander, I.H., Grice, P.V., Evans, A.D. (2005): Does organic farming benefit biodiversity? Biological Conservation 122: 113130. doi: 10.1016/j.biocon.2004.07.018

[23] Karaman, S. (1968): Uber eine neue Regenwurm Art aus Serbian, Allolobophora kosowensis n.sp. Zoologischer Anzeiger 181: 50-53.

[24] Krück, S., Joschko, M., Schultz-Sternberg, R., Kroschewski, B., Tessmann, J. (2006): A classification scheme for earthworm populations (Lumbricidae) in cultivated agricultural soils in Brandenburg, Germany. Journal of Plant Nutrition and Soil Science 169: 651-660.

[25] Linnaeus, C. (1758): Systema Naturae per Regna tria Naturae, secundum Classes, Ordines, Genera, Species, cum characteribus, differentiatiis, synonymis, locis. 10th edition, 1. Laurentii Salvii, Holmiae, pp. 824.

[26] Michaelsen, W. (1891): Oligochaeten des Naturhistorischen Museums in Hamburg IV. Jahrbuch der Hamburgischen Wissenschaftlichen Anstalten 8: 1-42.

[27] Minailova, P. (1964): Njakoj vidove ot semejstvo Lumbricidae (Oligohaeta) novi za faunata na Blgarija. Annuaire de Université de Sofia 57: 163-169. 
[28] Milutinović, T., Avramović, A., Pešić, S., Blesić, B., Stojanović, M., Bogdanović, A.M. (2010): Contribution to the knowledge of pedofauna in Sumadija (Central part of Serbia). Biotechnology and Biotechnological Equipment 24 (2): 628-635. doi: 10.1080/13102818.2010.10817911

[29] Milutinović, T., Milanović, J., Stojanović, M. (2015): Application of species richness estimators for the assessment of earthworm diversity. Journal of Natural History 49 (58): 273-283. doi: 10.1080/00222933.2013.791947

[30] MisirlioĞLU, M. (2012): Distribution of earthworms belonging to families Acanthodrilidae, Criodrilidae, and Megascolecidae in Turkey. Zoology in the Middle East 58 (4): 103-106. doi: 10.1080/09397140.2012.10648990

[31] MrŠIĆ, N. (1991): Monograph on earthworms (Lumbricidae) of the Balkans I-II. Slovenska Akademija Znanosti in Umetnosti, Ljubljana.

[32] MrŠIĆ, N., ŠAPKAREV, J. (1987): Survey of the earthworms (Lumbricidae) of Serbia in a restricted sense and description of new taxa. Biološki Vestnik 35: 67-86.

[33] ÖRLEY, L. (1881): Beitrage zur Lumbricinen-Fauna der Balearen. Zoologischer Anzeiger 4: $284-287$.

[34] Pelosi, C., Bertrand, M., Capowiez, Y., Boizard, H., Roger-Estrade, J. (2009a): Earthworm collection from agricultural fields: Comparisons of selected expellants in presence/absence of hand-sorting. European Journal of Soil Biology 45: 176-183. doi: 10.1016/j.ejsobi.2008.09.013.

[35] Pelosi, C., Bertrand, M., Roger-Estrade, J. (2009b): Earthworm community in conventional, organic and direct seeding with living mulch cropping systems. Agronomy for Sustainable Development 29: 287-295. doi: 10.1051/agro/2008069

[36] Pop, A.A., Pop, V.V., Csuzdi, C. (2010): Significance of the Apuseni Mountains (the Carpathians) inthe origin and distribution of Central European earthworm fauna (Oligochaeta: Lumbricidae). Zoology in the Middle East 2: 89-110. doi: 10.1080/09397140.2010.10638462

[37] Pop, V. (1948): Allolobophora mehadiensis Rosa var. boscaiu, une nouvele varite de Lumbricida de la Roumanie. Comptes Rendus du Cercle Zoologia 13: 13.

[38] Pop, V. (1949): Lumbricidele din România. Analele Academiei Republicii Populare Române 1 (9): 383-505.

[39] Rosa, D. (1884): Lumbricidi del Pieomonte. UTET, Torino.

[40] Rosa, D. (1893): Revisione dei lumbricidi. Memoire della Reale Academia delle Scienze di Torino (Serie 2) 43: 399-477.

[41] Rosa, D. (1895): Nuovi lombrichi dell'Europa orientale. Bollettino dei Musei di Zoologia ed Anatomia comparata della R. Universitá di Torino 10 (21): 1-8.

[42] ŠAPKAREV, J. (1978): Prilog poznavanju kišnih glisti (Oligochaeta: Lumbricidae) Vojvodine, Matica Srpska, Zbornik za Prirodne Nauke 54: 255-256.

[43] ŠAPKAREV, J. (1986): Nove kišne gliste Srbije. Macedonian Academy of Sciences 4: $297-$ 318.

[44] ŠAPKAREV, J. (1989): Description of new species of earthworms (Oligochaeta: Lumbricidae) from Yugoslavia. Macedonian Academy of Sciences and Arts 7 (1-2): 3336.

[45] Satchell, J.E. (1980): R worms and K worms: a basis for classifying lumbricid earthworm strategies. In Soil Biology as Related to Land Use Practices. Proceedings of the VII International Soil Zoology Colloquium, pp. 848-863.

[46] SAVigny, J.C. (1826): Analyses des travaux de l'Académie Royale des Sciences pendant l'année 1821, partie physique. In: Cuvier, G. (ed.) Memoires de l'Académie des Sciences de l'Institut de France, Paris 5: 176-184.

[47] Schmidt, O., Clements, R.O., Donaldson, G. (2003): Why do cereal-legume intercrops support large earthworm populations? Applied Soil Ecology 22: 181-190. 
doi: 10.1016/s0929-1393(02)00131-2

[48] Schmidt, O., Curry, J.P., Hackett, R.A., Purvis, G., Clements, R.O. (2001): Earthworm communities in conventional wheat monocropping and low-input wheat-clover intercropping systems. Annals of Applied Biology 138: 377-388. doi: 10.1111/j.17447348.2001.tb00123.x

[49] Scullion, J., Neale, S., PhilipPs, L. (2006): Comparisons of earthworm populations and cast properties in conventional and organic arable rotations. Soil Use and Management 18: 293-300. doi: 10.1111/j.1475-2743.2002.tb00271.x

[50] Stojanović, M., Milutinović, T. (2014): The earthworms (Oligochaeta: Lumbricidae) of the Pannonian region of Serbia, Vojvodina Province: Zoogeography and Diversity. North-Western Journal of Zoology 10 (2): 305--313.

[51] Stojanović, M., Milutinović, T., Karaman, S. (2008): Earthworm (Lumbricidae) diversity in the Central Balkans: An evaluation of their conservation status. European Journal of Soil Biology 44: 57-64. doi: 10.1016/j.ejsobi.2007.09.005

[52] Stojanović, M., Sekulić, J., Trakić, T. (2018): Checklist of earthworms (Oligochaeta: Lumbricidae) from Serbia: a review. Zootaxa 4496 (1): 124-155. doi: 10.11646/zootaxa.4496.1.9

[53] Stojanović, M., Trakić, T., Sekulić, J. (2020): Kišne gliste (Oligochaeta: Lumbricidae) Srbije. Novi Sad: Prirodno-matematički fakultet. pp. 278.

[54] Stojanović, M., Tsekova, R., Milutinović, T. (2014): Distribution of Lumbricus friendi Cognetti 1904 (Oligochaeta, Lumbricidae) at the European scale: First findings in Serbia. Bulgarian Journal of Agricultural Science 20 (S1): 110-112.

[55] SzEDERJESI, T. (2011): The earthworm fauna of the Karancs-Medves Landscape Protection Area (Oligochaeta, Lumbricidae. Opuscula Zoologica Budapest 42 (1): 6773.

[56] SzEDERJESI, T. (2013): New earthworm records from the former Yugoslav countries (Oligochaeta: Lumbricidae). Opuscula Zoologica Budapest 44 (1): 61-76.

[57] SzederJesi, T., Pop, V., Csuzdi, C. (2014): New and little known earthworm species from peripheral areas of the Romanian Carpathians (Oligochaeta, Lumbricidae). Acta Zoologica Academiae Scientiarum Hungarica, 60 (2): 85-107.

[58] SzÜTS, A. (1919): Beiträge zur kenntis der Lumbricidenfauna von Kroatien und Bosnien. Zoologischen Anzeiger 50: 294-298.

[59] WaGA, A. (1857): Sprawozdanie z podrózy naturalistów odbytej w r. 1854 do Ojcowa.

[60] ZICSI, A. (1972): Ein neuer Wiederfund von Allolobophora dofleini Ude 1922. Annales Universitatis Scientiarium Budapestinensis 14: 241-245.

[61] ZICSI, A. (1985): Regenwürmer (Oligochaeta: Lumbricidae) aus Israel und den benachbarten Ländern. Revue suisse de Zoologie 92: 323-331.

[62] ZICSI, A. (1991): Über die Regenwürmer Ungarns (Oligochaeta: Lumbricidae) mit Bestimmungstabellen der Arten. Opuscula Zoologica Budapest 24: 167-191.

[63] ZiCsi, A., Dózsa-Farkas K., CsuZdi C. (1999): Terrestrial oligochaetes of the Aggtelek National Park. In: Mahunka, S. (ed.) The fauna of the Aggtelek National Park. Hungarian Natural History Museum, Budapest, 39-43. 